\title{
Towards a database on societal impact of Mediterranean floods within the framework of the HYMEX project
}

\author{
M. C. Llasat ${ }^{1}$, M. Llasat-Botija ${ }^{1}$, O. Petrucci ${ }^{2}$, A. A. Pasqua ${ }^{2}$, J. Rosselló ${ }^{3}$, F. Vinet $^{4}$, and L. Boissier ${ }^{4}$ \\ ${ }^{1}$ GAMA (Meteorological Hazards Analysis Team) Department of Astronomy and Meteorology Faculty of Physics, \\ University of Barcelona, Barcelona, Spain \\ ${ }^{2}$ CNR-IRPI (Istituto di Ricerca per la Protezione Idrogeologica), Cosenza, Italy \\ ${ }^{3}$ Grup de Climatologia, Hidrologia, Riscs i Territori. Universitat Illes Balears, Palma de Mallorca, Spain \\ ${ }^{4}$ Laboratoire GRED. Université Montpellier 3/IRD, France
}

Correspondence to: M. C. Llasat (carmell@am.ub.es)

Received: 30 October 2012 - Published in Nat. Hazards Earth Syst. Sci. Discuss.: -

Revised: 15 February 2013 - Accepted: 18 February 2013 - Published: 24 May 2013

\begin{abstract}
The NW Mediterranean region experiences every year heavy rainfall and flash floods that occasionally produce catastrophic damages. Less frequent are floods that affect large regions. Although a large number of databases devoted exclusively to floods or considering all kind of natural hazards do exist, usually they only record catastrophic flood events. This paper deals with the new flood database that is being developed within the framework of HYMEX project. Results are focused on four regions representative of the NW sector of Mediterranean Europe: Catalonia, Spain; the Balearic Islands, Spain; Calabria, Italy; and LanguedocRoussillon, Midi-Pyrénées and PACA, France. The common available 30-yr period starts in 1981 and ends in 2010. The paper shows the database structure and criteria, the comparison with other flood databases, some statistics on spatial and temporal distribution, and an identification of the most important events. The paper also provides a table that includes the date and affected region of all the catastrophic events identified in the regions of study, in order to make this information available for all audiences.
\end{abstract}

\section{Introduction}

The HYMEX (Hydrological Mediterranean Experiment) is an interdisciplinary and multidisciplinary project that analyses all the components involved in the water cycle in the Mediterranean, with emphases on the predictability and evolution of intense events by monitoring and modelling the Mediterranean coupled system and its variability in the context of global change (for more information see http: //www.hymex.org). The project is structured into five working groups, two of which have a direct relationship with floods and/or flash floods: the WG3, which deals with heavy precipitation and flash flooding, mainly from the hydrometeorological point of view; and the WG5, which focuses on evaluating the societal and economical impact of extreme events and climate change and the adaptation capacity.

Contributions from the HYMEX project to the knowledge of floods and flash floods are numerous and include very different approaches. Indeed, solely in terms of societal impact analysis, it can be addressed from different points of view and disciplines (Llasat et al., 2011a) that range from analysis of social perception and communication (Llasat et al., 2009, 2011b) to the various kinds of vulnerability analysis (Lumbroso and Vinet, 2011), including studies focusing on damage and claims to insurance companies or meteorological services (Amaro et al., 2011; Barberia et al., 2011; Barredo et al., 2012), warning processes and temporal variability or climate change impact (Grimalt and Rosselló, 2010; Llasat et al., 2010a). An important activity of WG5 members is the reconstruction of past floods and flash floods events using post-event surveys (Ruin et al., 2008), research for historical information (Grimalt and Rosselló, 2011) and the building of databases as sources of information (Llasat et al., 2010b, 2011c).

The implementation of databases requires an enormous effort not always recognised. The initial problem lies in the 
data required for this kind of approach. This clearly depends on the research objective, but the most usual are data from insurance companies, newspapers, specific post-event questionnaires, damage refund requests or technical reports, which in most cases have to be completed with hydrometeorological data. Problems due to heterogeneity, lack of data and incorrect information accepted as public and published can be the source of intrinsic mistakes (Petrucci, 2012; Petrucci and Pasqua, 2008, 2009; Polemio and Petrucci, 2012), and it is not unusual to find contradictory data on damage, number of victims (especially for the oldest events), date of the events, and so on. However, having good quality information from past flood events is imperative for improving flood damage assessment, as the EU Floods Directive $(2007 / 60 / \mathrm{EC})$ indicates and the present COST Action ES0901 (FloodFreq) and the recently started project of the European Research Council, FloodChange, confirm.

Building a database on heavy rainfalls and floods in the Mediterranean region is not a new question. In 1991, the AMHY/FRIEND project from UNESCO (Alpine and Mediterranean Hydrology-Flow Regimes from International Experimental and Network Data) started a database that included - in addition to rainfall and flow data for different stations - heavy rainfall and flood events (Llasat et al., 1999; Servat et al., 2002) and that clearly revealed the great differences concerning the concept of "heavy rainfall" in different countries and the difficulty of obtaining objective data for flood events. Some years after, the WMO/WCRP project MEDEX (Mediterranean Experiment) made a selection of the major flood, heavy rainfall and storm events in the Mediterranean, recorded between 1996 and 2001, in order to undertake a complete meteorological analysis thereof and relate them with potential cyclogenesis phenomena. This database was extended to the whole period 1990-2006 by the Societal Impact Research Group of MEDEX and by the European FLASH project (Price et al., 2011). The major flash-flood events analysed within the framework of the HYDRATE project (Gaume et al., 2009), were also considered. A total of 185 flood events that had occurred in the Mediterranean region were identified for the period 1990-2006. The work revealed the numerous difficulties in obtaining information from some regions or countries, criteria disagreements and lack of data. In spite of this, it was an advance in the knowledge of the Mediterranean distribution of floods. The question thus remains open.

The database presented in this study centres on some specific regions of Spain, France and Italy in which flash floods are frequent, although the idea is to include more regions in the future. To state some figures that show the importance of these regions: on 25 September 1962 a flash flood in Catalonia produced more than 815 casualties and 2650 million Ptas-worth (more than 532.7 Million Euros in inflation-adjusted (2011) values) of direct material losses; the flash-flood event of 8 and 9 September 2002 affected a total number of 6 French Departments, with damage of

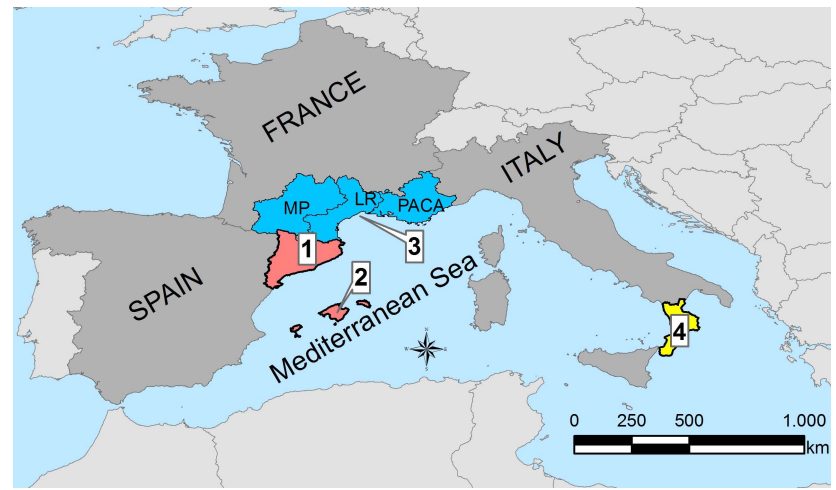

Fig. 1. Selected regions for building the preliminary HYMEX database.

1200 million $€$ (830 million for the Department of Gard, Languedoc-Roussillon) and 25 casualties. In Calabria, one of the severest events occurred in 1951, causing 101 victims and leaving 4500 homeless: road interruptions were so numerous that communications between coastal villages were possible only by sea. More recently, in September 2000, a local flood event with debris flow affected a campsite located in Soverato, leaving 13 casualties. In the Balearic Islands, the 6 September 1989 flash flood affecting the eastern coast of Mallorca produced 3 casualties and damage to tourist infrastructures, private houses, streets, roads and bridges; a total economic valuation of thousands of millions of pesetas in damage was made and the area received official help following its declaration as catastrophe zone.

The paper starts with a brief introduction about the actual databases on floods, moves then to a presentation of the HYMEX database and follows with the presentation of some results and their temporal and spatial distribution.

\section{Selected regions for building the preliminary floods database of HYMEX}

Figure 1 shows the regions selected for this study, while some of their main geographic and climatic features are showed in Table 1. The selected regions are Catalonia and the Balearic Islands in Spain, Languedoc-Roussillon, Midi-Pyrénées and Provence-Alpes Côte d'Azur in France, and Calabria in Italy. These regions were selected because they constitute a representative example of the NW Mediterranean region, and the authors of this paper have direct access to the information that has been introduced in the database, a factor that favours future homogenization of criteria and discussions, quality controls, and so on. There are two regions that are representatives of Mediterranean Spain, the third region is in the south of Italy and the last three are representative of the south of France, where flash-floods are frequent. 
Table 1. Main features of the selected regions.

\begin{tabular}{|c|c|c|c|c|c|c|c|}
\hline No. & Country & $\begin{array}{l}\text { Administrative } \\
\text { region }\end{array}$ & Acronym & $\begin{array}{r}\text { Area } \\
\left(\mathrm{km}^{2}\right)\end{array}$ & $\begin{array}{l}\text { Mean (or } \\
\text { minimum/ } \\
\text { maximum) } \\
\text { altitude m a.s.l. }\end{array}$ & $\begin{array}{l}\text { Pop. } \\
\text { density } \\
\left(\text { Inh km }^{-2}\right)\end{array}$ & $\begin{array}{l}\text { Mean } \\
\text { annual } \\
\text { rain } \\
(\mathrm{mm})\end{array}$ \\
\hline 1 & Spain & Catalonia & CAT & 32107 & 700 & 231.5 & $\begin{array}{l}\text { From } 400 \mathrm{~mm} \\
\text { in the south to } \\
1200 \mathrm{~mm} \text { in the } \\
\text { Pyrenees }\end{array}$ \\
\hline 2 & Spain & Balearic Islands & BAL & 4492 & 138 & 222.97 & 550 \\
\hline 3 & France (SE) & $\begin{array}{l}\text { Languedoc-Roussillon } \\
\text { Midi-Pyrénées } \\
\text { Provence-Alpes-Côte d'Azur }\end{array}$ & $\begin{array}{l}\text { F-LR } \\
\text { F-MP } \\
\text { F-PACA }\end{array}$ & $\begin{array}{l}27376 \\
45348 \\
31400\end{array}$ & $\begin{array}{l}80-1950 \\
130-2553 \\
100-1750\end{array}$ & $\begin{array}{l}95 \\
63 \\
156\end{array}$ & $\begin{array}{l}880 \\
940 \\
850\end{array}$ \\
\hline 4 & Italy & Calabria & CAL & 15230 & 418 & 132 & 1151 \\
\hline
\end{tabular}

\section{Comparison between different criteria and existing flood databases}

The first step when a new database on flood events is built is to define the criteria to select the events and data that will be included, as well as which could constitute added value of this effort in the light of the databases already existing. Nowadays, most of the studies focusing on the economic and societal impact in a region are based on global databases (Table 2), usually the Natural Hazards Assessment Network (NATHAN) of the reinsurance firm Munich Re, or the Emergency Events Database (EM-DAT) from the Centre for Research on the Epidemiology of Disasters of the Université Catholique de Louvain (Barredo, 2009). These databases are also used to identify major events, drawing up comparative statistics and writing official reports that can be determinant in policymakers' decisions. One reason is the large area covered by the databases, but the second one lies in the difficulty of obtaining data about damage and recovery from national and private insurance companies and national and local administrations. These databases provide very useful information about catastrophic events, but for regional or local studies it is necessary to consider it with caution because, usually, they have a built-in bias towards indirect sources or consider only the information provided by some insurance companies that do not cover the entire affected regions. A second question lies in the lack of unanimity of criteria for selecting events that can be due to various reasons, such as disagreement over the evaluation of damage from different points of view, the difficulty of obtaining quantitative information and the agenda.

Another possibility involves working with national or regional flood databases, such as those included in Table 3 . The PRIM-NET database (MEDDTL, 2011) refers to all natural disasters in France and only includes catastrophic events; for this analysis only data for Languedoc-Roussillon Midi-
Pyrénées and PACA have been considered. The Spanish floods database of the Civil Protection agency contains the major floods recorded in Spain from 1995 to 2010, but due to restrictive economic conditions it had not been updated at the moment for some regions, including Catalonia. In this case there are no specific criteria for deciding whether or not an event should be included in the database, though generally all the main events are recorded. The "Consorcio de Compensación de Seguros", a Spanish national reinsurance company (Barredo et al., 2012) also has a database, but it is not for public distribution. For Italy, the national database of landslides and floods that occurred in the 20th century, named AVI, was available; data essentially came from newspapers, and historically affected areas were mapped at 1:100000 scale (Guzzetti et al., 1994). The sources for building these databases were very heterogeneous, including press news, insurance data, reports from different companies or university groups and so on.

Finally, it is also possible to find local or regional databases (Table 4). These have been usually developed within the framework of regional administration orders, or supported by public projects plus non-financed work (i.e. INUNGAMA), or, as for ASICAL, within the framework of collaborations between public research institutions (i.e. CNR-IRPI and the University of Calabria). The advantage of these databases lies in the possibility of having more detailed information obtained from detailed surveys undertaken at regional or sub-regional scale. Table 5 shows an example of the most usual procedure followed for building local/regional databases: it is a long and hard process that is usually only evaluated in its complexity by those that have participated in similar processes.

The ASICAL (Italian acronym for historically flooded areas in Calabria) floods and landslides database contains events since the 19th century (Petrucci and Pasqua, 2008, 2009 ) in the Calabria region (southern Italy). Data came from 
Table 2. Largest public world databases on disaster events that include flood events (more information is available at http://www.emdat.be/, http://www.munichre.com, www.eswd.eu., http://www.dartmouth.edu/ floods/Currentt.htm, http://www.swissre.com/sigma/).

\begin{tabular}{|c|c|c|c|c|c|c|}
\hline Database & Coverage & Kind of events & Criteria & Start date & Owner & Public access? \\
\hline $\begin{array}{l}\text { EM-DAT- } \\
\text { Emergency } \\
\text { Events } \\
\text { Database }\end{array}$ & Global & $\begin{array}{l}\text { Natural and } \\
\text { technological } \\
\text { disasters }\end{array}$ & $\begin{array}{l}\text { At least one of the following criteria: (a) } \\
10 \text { or more people killed; (b) } 100 \text { or more } \\
\text { people affected/injured/homeless; (c) dec- } \\
\text { laration of state of emergency; (d) appeal } \\
\text { for international assistance. }\end{array}$ & 1900 & $\begin{array}{l}\text { Univ. Catholique de } \\
\text { Louvain, Belgium }\end{array}$ & Yes \\
\hline $\begin{array}{l}\text { NATHAN- } \\
\text { Natural } \\
\text { Hazards } \\
\text { Assessment } \\
\text { Network }\end{array}$ & Global & $\begin{array}{l}\text { Natural hazard- } \\
\text { based disasters }\end{array}$ & $\begin{array}{l}\text { Great natural catastrophes: supra-regional } \\
\text { or international assistance is required; } \\
\text { thousands of fatalities; hundreds of thou- } \\
\text { sands of people homeless; or when the } \\
\text { overall losses and/or insured losses reach } \\
\text { exceptional orders of magnitude. }\end{array}$ & 1974 & $\begin{array}{l}\text { Munich Re } \\
\text { Germany }\end{array}$ & Partially \\
\hline $\begin{array}{l}\text { ESWD- } \\
\text { European Se- } \\
\text { vere Weather } \\
\text { Database }\end{array}$ & European & $\begin{array}{l}\text { Severe } \\
\text { convective } \\
\text { storms }\end{array}$ & $\begin{array}{l}\text { No common criteria. Information is } \\
\text { reported by the sources }\end{array}$ & 2006 & $\begin{array}{l}\text { European Severe } \\
\text { Storms Laboratory } \\
\text { Germany }\end{array}$ & Yes \\
\hline $\begin{array}{l}\text { Swiss Re } \\
\text { (Sigma) }\end{array}$ & Global & $\begin{array}{l}\text { Natural and } \\
\text { man-made } \\
\text { disasters }\end{array}$ & $\begin{array}{l}\text { Losses of US } \$ 86.6 \mathrm{M} \text { and/or insured } \\
\text { losses of US } \$ 43.3 \mathrm{M} \text { (both in } 2010 \text { val- } \\
\text { ues) and/or } 20 \text { fatalities/people missing }\end{array}$ & 2003 & Swiss $\operatorname{Re}$ & Partially \\
\hline
\end{tabular}

Table 3. National databases on flood events for Italy, Spain and France.

\begin{tabular}{lllllll}
\hline Database & Coverage & $\begin{array}{l}\text { Kind of } \\
\text { events }\end{array}$ & Criteria & Start date & Owner & Public access? \\
\hline $\begin{array}{l}\text { Database of the French } \\
\text { Ministry of Ecology } \\
\text { (PRIM.NET) }\end{array}$ & France & Natural & $\begin{array}{l}\text { Any event in the whole } \\
\text { country that triggered at } \\
\text { least 3 million euros of } \\
\text { damage and/or one death. }\end{array}$ & 1900 & $\begin{array}{l}\text { PRIM.NET, French } \\
\text { Ministry of } \\
\text { Environment }\end{array}$ \\
\hline Civil Protection & Spain & Natural & Major flood events & 1995 & $\begin{array}{l}\text { Spanish } \\
\text { Civil Protection }\end{array}$ \\
\hline AVI & Italy & $\begin{array}{l}\text { Floods and } \\
\text { landslides }\end{array}$ & No event selection criteria & 1918 & CNR-IRPI & Partially \\
\hline
\end{tabular}

various sources such as newspapers, archives of national and regional agencies, scientific and technical reports, and so on. For more recent cases, on-site survey reports drawn up during the event emergency management by the staff of either CNR-IRPI or regional agencies such as Civil Protection and River Basins Authority are also available, as well as information collected by interviewing the people involved and local administrators. This database has been continuously updated by both the results of local historical research (Petrucci et al., 2012) and data coming from the daily survey of regional newspapers; currently it contains about 2300 records of floods that occurred in the most intensely studied period, between 1880 and 2011. In fact, even if flood damage data are available for oldest epochs, the historical research is usually focused on the period for which hydrological data also started to be available; for the majority of Calabria rain gauges this coincides with the end of 19th century/beginning of 20th century (Polemio and Petrucci, 2012). On the other hand, data on river flows are almost absent, mainly because of the torrential regimen of Calabrian water courses, locally known as "fiumare" and widely diffused throughout the entire Mediterranean basin.

The INUNGAMA floods database refers to Catalonia (Northeast Spain) and was created in 2007 (Barnolas and Llasat, 2007a). This database also includes floods for the three main rivers in Catalonia, since the 14th century (Barnolas and Llasat, 2007b), and recently it has been updated to complete the present study. This database considers 
Table 4. Regional databases on flood events, for some regions of Italy and Spain.

\begin{tabular}{|c|c|c|c|c|c|c|}
\hline Database & Coverage & Kind of events & Criteria & Start date & Owner & $\begin{array}{l}\text { Public } \\
\text { access? }\end{array}$ \\
\hline ASICAL & $\begin{array}{l}\text { Calabria } \\
\text { (Italy) }\end{array}$ & $\begin{array}{l}\text { Floods, landslides, } \\
\text { and heavy rain }\end{array}$ & $\begin{array}{l}\text { All the events for which infor- } \\
\text { mation exists in the press or in } \\
\text { other sources }\end{array}$ & $\begin{array}{l}\text { Beginning of } \\
19 \text { th century }\end{array}$ & CNR-IRPI & Partially \\
\hline INUNGAMA & $\begin{array}{l}\text { Catalonia } \\
\text { (Spain) }\end{array}$ & Floods & $\begin{array}{l}\text { All the floods with information } \\
\text { in the press or impacts. }\end{array}$ & 1900 & GAMA-UB & No \\
\hline UIB & $\begin{array}{l}\text { Balearic } \\
\text { Islands } \\
\text { (Spain) }\end{array}$ & Floods & $\begin{array}{l}\text { All the events for which infor- } \\
\text { mation exists in the press or in } \\
\text { other sources }\end{array}$ & 1403 & $\begin{array}{l}\text { Univ. } \\
\text { of Balearic } \\
\text { Islands }\end{array}$ & No \\
\hline
\end{tabular}

all the events that have produced any minor or major societal impact. The main source of information for the last $30 \mathrm{yr}$ has been the press, because for non-permanent torrential rivers, the ones most frequently affected by floods, systematic river flow data are unavailable. However, some scientific reports and hydrometeorological data have also been used to complete the information. Usually, insurances companies do not provide detailed information for each event, and only for some specific cases was it possible to recover it. Overall, for the period 1900-2010, this database contains 365 flood and flash-flood events, which are included in a GIS support.

The University of Balearic Islands floods database contains heavy rainfall and flash flood events recorded between 1403 and 2011 for the islands of Majorca, Menorca, Ibiza and Formentera. It is updated yearly if information about events exist. The selection criteria were the existence of information about a flood event. The dates of the events and the affected basins and catchments were located using sources such as regional newspapers, local weekly papers, and regional and local administration reports and theses (i.e. Grimalt, 1992). On-site survey data was used mainly for the period 1990-2010.

\section{The common database}

The period 1981-2010 has been selected as reference in order to have a minimum period of $30 \mathrm{yr}$ in length that could be considered as a climatic period. This restriction has allowed filling each local database with more information in order to achieve a "homogeneous" period in the sense that any heterogeneity would have been introduced as a consequence of non-systematic research.

Taking as a departure point the databases presented previously for Catalonia (INUNGAMA) and the Balearic Islands (the UIB Database), Languedoc-Roussillon, Midi-Pyrénées and PACA (PRIM-NET) and Calabria (ASICAL) (Fig. 1), and after a completion process, a common database has been built. The final idea is to define a methodology that could be applied to other regions in order to obtain a homogeneous and complete Mediterranean flood database (the HYMEX Societal Impact database, FLOODHYMEX).

A common database called FLOODHYMEX has been built using EXCEL. For each event information about the following items were sought:

- Date; it contains the first and last day of the entire event, i.e. from the initial day of heavy rainfalls to the day of the last floods.

- Information about the event localization:

- country,

- region - administrative region affected by the event (i.e. Department of Midi-Pyrénées);

- main areas affected by the event - using the internal administrative boundaries of each region in each country (county, municipality, etc.);

- overflowed river catchment, when known.

- Kind of event: floods (FL), flash floods (FF), landslides (LS). Usually the identification of flash flood is furnished by the data provider; on the other hand, all the events that last one day or less are considered as flash flood. Other secondary phenomena that can be simultaneous with the precipitation event are also included: TO (tornado), HL (hail), SN (snow), and SW (strong wind). Thunderstorms were not included because it is difficult to have systematic information about lightning production over the entire period.

- Main hydrometeorological features: some hydrological (maximum peak flow and/or daily flow) and meteorological data (maximum precipitation recorded in $24 \mathrm{~h}$ and/or during the entire event), and river and place in which they were recorded. This information is not available for all the cases, because for most of them no gauge station exists. The objective of this information is to obtain a preliminary approach to the magnitude of the event. 
Table 5. Main steps in the creation of local flood databases (Polemio and Petrucci, 2012).

\begin{tabular}{ll}
\hline Activities & Steps \\
\hline \multirow{3}{*}{ Data gathering } & $\begin{array}{l}\text { (1) Analysis of existing databases } \\
\text { (2) Selection of archives to look through } \\
\text { (3) Planning the historical research } \\
\text { (4) Performing data collection }\end{array}$ \\
\hline $\begin{array}{l}\text { Historical database } \\
\text { construction }\end{array}$ & $\begin{array}{l}\text { (1) Conversion of historical documents into text files } \\
\text { (2) Disaggregation of data according to damage sites } \\
\text { (3) Chronological sorting of data }\end{array}$ \\
\hline
\end{tabular}

Table 6. Number of events that produced floods $\left(\mathrm{N}_{e}\right)$ identified in the FLOODHYMEX database; $N_{\mathrm{e}}$ Ext (number of extraordinary flood events); $N_{\mathrm{e}}$ Cat (number of catastrophic flood events); and total number of deaths. The period analysed is 1981-2010. Between brackets is the number of events which caused casualties.

\begin{tabular}{lrrrr}
\hline & $N_{\mathrm{e}}$ & $N_{\mathrm{e}}$ Ext & $N_{\mathrm{e}}$ Cat & $\begin{array}{r}\text { Number of } \\
\text { deaths }\end{array}$ \\
\hline SE France & $29(17)$ & $0(0)$ & $29(17)$ & 186 \\
Calabria & $107(7)$ & $40(0)$ & $36(7)$ & 26 \\
Catalonia & $213(42)$ & $114(18)$ & $22(15)$ & 110 \\
Balearic I. & $36(6)$ & $28(1)$ & $8(5)$ & 11 \\
\hline Total & $385(72)$ & $182(19)$ & $95(44)$ & 333 \\
\hline
\end{tabular}

- Information about casualties:

- number of casualties;

- circumstances related with the deaths - people dragged away by water while they were crossing the fluvial course, dead in a campsite, dead in a building or due to an accident or unknown causes;

- number of casualties estimated in EM-DAT and NATHAN databases;

- number of injured people, when such information is available.

- Information about damage:

- damage description - the indicators defined to distinguish between different kinds of damage included roads/streets, bridges, cars dragged away (and number), railways, buildings, monuments/historical sites, electricity/telephone lines, aqueducts/drainage systems/gas pipelines, embankments/dams/retaining walls, industry, commerce/handcraft, tourism, agriculture/farming, public services malfunction.

- Economic evaluation: this section relates to local damage (where known) or total damage. Where known, the insured damages are also shown.
- Preliminary common classification on the basis of flood impact and following the criteria shown in Llasat et al. (2005): 0 (ordinary), 1 (extraordinary), 2 (catastrophic). This kind of classification is usual when historical floods are analysed (Camuffo and Enzi, 1996; Barriendos et al., 2003; Barrera et al., 2006).

- Documentation sources.

The main problems found when the common database had been built were the following:

- to find river flow data; this happens because Mediterranean rivers typically show an ephemeral regimen, which hampers systematic discharge measurements.

- To find rainfall data and select data sufficiently representative (in space and time) of the hydrometeorological severity of the event. Some indicators on the duration of the rain and the extent of the area to be analysed (in term of rainfall) should be defined.

- To find an objective criterion to separate one event from another, during prolonged rainy periods.

- To have accurate information about damage (public and private) and casualties. In some countries data from insurance companies are not public. The most usual situation in bibliography is working with factors involved in losses of life (Jonkman and Vrijling, 2008; Di Mauro et al., 2012; Ruin et al., 2008).

- To find data sources that can be considered reliable, we often use newspapers, but a large part of the scientific community considers this kind of source unreliable.

- The accuracy of damage data included in a data-series can vary greatly, and in such cases data should be labelled according to their level of detail.

- To find a criterion to geographically reference damage data, because floods affected areas that can be delimited only by means of on-site surveys (which cannot be performed for past events). 
Table 7. Circumstances in which casualties occurred in the different FLOODHYMEX study areas.

\begin{tabular}{lrrrr}
\hline Circumstances of casualties & Catalonia & SE France & Calabria & Balearic I. \\
\hline Dragged by water & 61 & 49 & 11 & 3 \\
Accidents & 19 & 42 & 0 & 0 \\
In a building & 7 & 65 & 0 & 4 \\
On a campsite & 0 & 21 & 13 & 0 \\
Not known & 23 & 9 & 2 & 4 \\
\hline Total & 110 & 186 & 26 & 11 \\
\hline
\end{tabular}

- To set a table of damageable elements and indicators that is simple and usable in different geographical contexts.

- Some minor flood events are not reported in the press and go unnoticed; on the other hand, "major" databases only contain catastrophic events and can introduce an overestimation of the effects of these events.

\section{Regional distribution}

385 flood events (ordinary, extraordinary and catastrophic) were recorded for the six regions and for the period 19812010. $19 \%$ of these events produced casualties, and $61.1 \%$ of that percentage can be attributed to catastrophic floods. Table 6 shows that the maximum contribution is the one from Catalonia, which also includes minor floods. Most particularly, in this region only $10.3 \%$ of the flood events can be considered as catastrophic, $53.5 \%$ can be classified as extraordinary flood events, while $36.2 \%$ are only ordinary floods. The percentage of catastrophic events recorded in Calabria and the Balearic Islands was 33.6 and $22.2 \%$, respectively, while these figures for extraordinary floods are 37 and $77 \%$, respectively. This fact shows the great contribution of extraordinary floods in the Balearic Islands. In the case of the French regions only catastrophic floods have been included.

A comparison with the EM-DAT and NATHAN databases shows that these global databases do not include all the catastrophic events that had arisen in a region; only 23 cases from 385 flood events have been recorded in the EM-DAT database and this figure decreases to 8 cases when we refer to the NATHAN. The case of Catalonia is relevant, with only one flood event included in the NATHAN database, and only 6 in the EM-DAT database, when more than 210 flood events producing damage have been identified. It is interesting to note that NATHAN does not report any event for Calabria (or for the Balearic Islands), even though the so-called Soverato event (SE Calabria), which killed 13 people, and after which the Italian government issued a decree imposing the mapping of hydrogeological risk in urbanised sectors, occurred in 2000, then in the period covered by the Munich Re database. In the same line, southeast France has recorded 29 catastrophic events on the period 1981-2010, of which only 12 are included in the NATHAN database.

Another interesting observation is that non-catastrophic events can also cause deaths. In the case of Catalonia, $38 \%$ of the deaths have been as a consequence of extraordinary or ordinary floods, similar in this case to the Balearic Islands, with $36.56 \%$. They were usually people dragged along by flash floods when crossing torrential streams, and could usually have been avoided if more precautions had been taken. Table 7 shows that this is the most usual cause of their death. Events that seriously affect a campsite are not frequent, but in the cases that do occur, they are very catastrophic. This is the case of the flash flood that occurred on 7 September 2000 (Calabria, Soverato), with 13 casualties, and of another on 22 September 1992 in France (Vaison-La-Romaine, Paca, Vaucluse Dept.) that led to 47 deaths ( 15 were in a campsite). People who died as an indirect consequence of the floods have been also considered in the database (i.e. the case of a woman who died of a heart attack when her home was inundated).

The Appendix Table A1 contains all the catastrophic floods recorded between 1981 and 2010 in the selected regions. The objective of this table is to give the reader information for future studies, and it has not been analysed in depth in this study. This is the reason why only some general comments will be made. A total number of 95 events have been identified, but in light of present knowledge of the evolution and tracking of Mediterranean storms, it is possible to identify some potential common catastrophic events that affected two or more regions. This is the case, for instance, of the event recorded between 5 and 9 September 2005 that produced flash floods in the Catalonia (Spain) and PACA (France) regions, and that also recorded a tornado and some waterspouts near Barcelona, and more than 36400 lightning flashes in Catalonia. The highest accumulated precipitations during the entire event were of $165 \mathrm{~mm}$ in $48 \mathrm{~h}$ in Catalonia, where more than $100 \mathrm{~mm}$ were recorded in $24 \mathrm{~h}$, but it was worst near the Cevennes, where $210 \mathrm{~mm}$ were recorded in $3 \mathrm{~h}$ on 6 September, and maximum total precipitation recorded in $48 \mathrm{~h}$ was $324 \mathrm{~mm}$. As a consequence of this catastrophic event, 2 people died in France and 2 more in Spain; material losses surpassed 9 million euros in Catalonia, and 90 million euros in France. It was not the first time that a catastrophic 


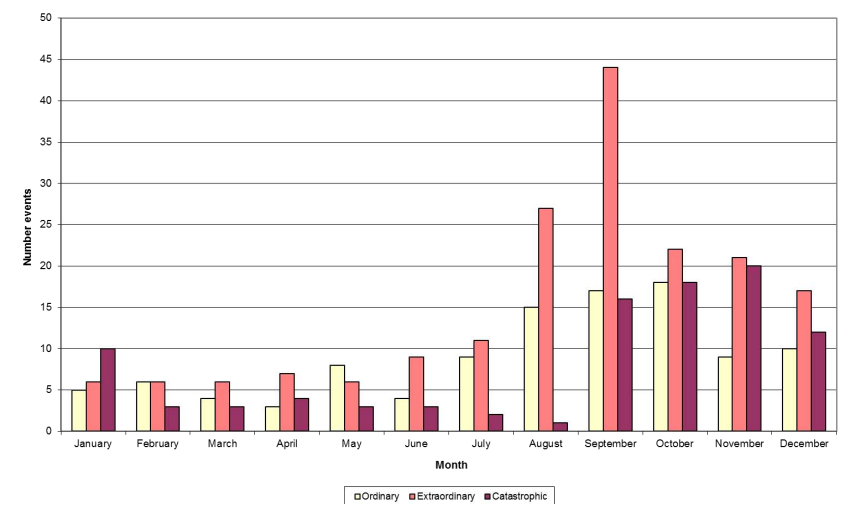

Fig. 2. Monthly distribution of flood events by category for the period 1981-2010, all the regions.

flood event occurring in SE France had started in Spain (i.e. September 1992, November 1982 or November 1988), a fact that points to the importance of having a collaborative strategy to improve early warning.

When a catastrophic flood arises, the most usual effect is on the roads and railways network: nearly all these events have caused cuts in roads, streets and railways (with partial destruction on some occasions), and $44 \%$ have damaged or destroyed some bridges. The services sector is also usually affected, and nearly $55 \%$ of the events caused interruptions of electricity and telephone lines, while a similar percentage of events caused damage to other public infrastructures such as aqueducts, drainage systems, embankments, dams or retaining walls. Of 95 events, more than $75 \%$ caused major damage to buildings and nearly $17 \%$ to monuments and historical sites. This high percentage reveals again the problem of urbanisation in flood-prone areas. Finally, the direct damage distribution by productive activities was also analysed on the basis of the number of events that had affected each sector. Results show that the worst affected one was agriculture (62\% of the cases), followed by commerce and handcraft $(54 \%)$, tourism $(45 \%)$ and industry $(29 \%)$.

\section{Temporal distribution}

Figure 2 shows the monthly distribution of flood events by category. Although floods can occur at any time of the year, we could consider the "flood season" to be from August to January, with a maximum in autumn $(48.1 \%)$ of the events. This percentage is close to that of $54.7 \%$ obtained for the Mediterranean region as a whole for the period 1990-2006 (Llasat et al., 2010b). The autumn contribution is particularly important for the Balearic Islands and SE France, with more than $60 \%$ of the flood events concentrated in that season, but it is also important to insist on the high frequency of summer floods in Catalonia, with a percentage of $32.4 \%$, and winter floods in Calabria, with its maximum annual percentage of $40.2 \%$ (Fig. 3). Of the total number of catastrophic

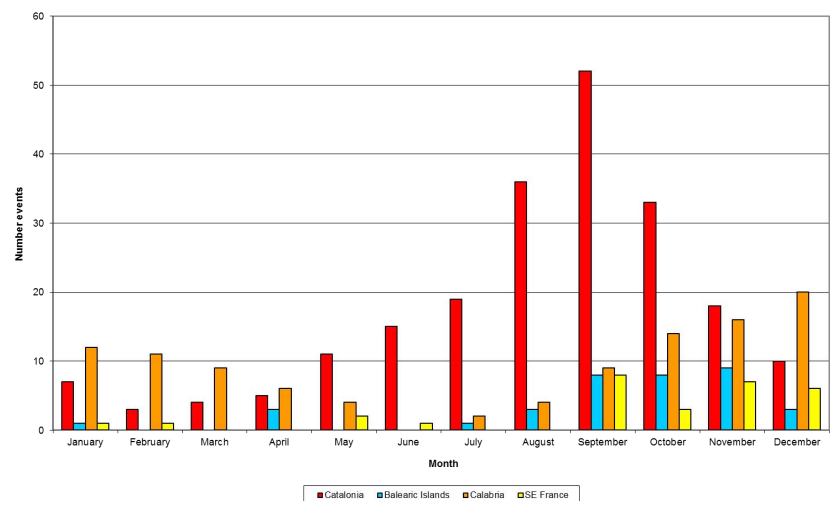

Fig. 3. Monthly distribution of flood events by region for the period 1981-2010.

floods (Fig. 4), more than $18 \%$ were recorded in Catalonia during the summer months, with $9 \%$ in June. September is the "worst" month in SE France, because it registers $27.6 \%$ of the total annual catastrophic floods, while for the Balearic Islands it is October (50\%), and for Catalonia the distribution between October and November is the same, with $27 \%$ for each month. The behaviour of Calabria is completely different, having a maximum in January of $25 \%$. This fact is consistent with the annual rainfall distribution in this region that records a maximum in winter, compared with the bimodal monthly distribution more typical of the other regions (Altava-Ortiz et al., 2010). March is the month with the smallest number of catastrophic floods, with Calabria being the only region that has recorded some cases in the period of study. Then, from a regional point of view, Catalonia, the Balearic Islands and SE France can be considered in the same "flood" region, characterised by a maximum concentration of catastrophic floods in autumn, with percentages that range from $62.1 \%$ for SE France, to $87.5 \%$ for the Balearic Islands). On the other hand, Calabria presents a more homogeneous distribution of catastrophic floods between autumn $(33.3 \%)$ and winter $(44.4 \%)$.

Floods occurring in summer and autumn are usually flash floods that mainly affect small and torrential catchments in the coastal region, causing the largest number of casualties, mainly due to high population density in the affected zone, the lack of knowledge of the people about the danger of torrential flows, and/or some difficulties in emergency management (Fig. 5). In this sense, $18.7 \%$ of the total number of events produced one or more casualties. Catalonia and SE France experienced the greatest number of casualties, with 110 and 186, respectively, and it is important to note the fatal impact of some extraordinary floods arising in August among tourists and people on holiday. Indeed, 10 people died in Catalonia in August over the period of study.

The interannual analysis for this period of 30 years does not show any trend for catastrophic floods in any of the regions (Fig. 6), a fact that is in agreement with studies 


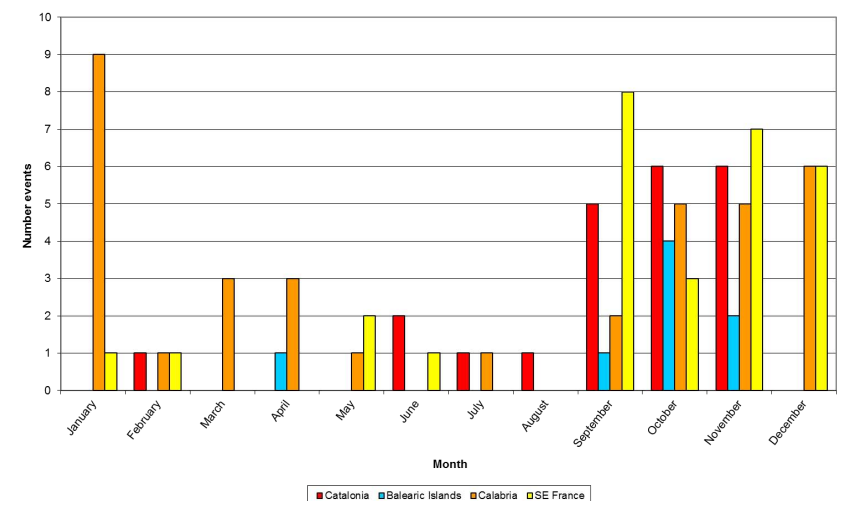

Fig. 4. Monthly distribution of catastrophic floods (1981-2010).

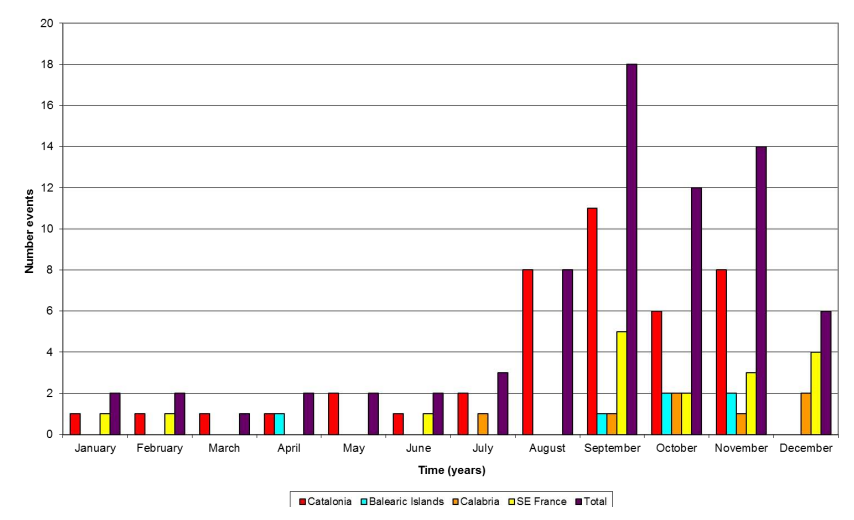

Fig. 5. Monthly distribution of events that caused victims (19812010).

relating to the longest series (Llasat et al., 2005). On the other hand, extraordinary floods show a positive trend in Catalonia, mainly related with the increase of autumn flash floods and their impact due to increasing urbanization in flood-prone areas near torrential and non-permanent streams, on the coast (Llasat et al., 2010a), as well as in Calabria, although in this case it is not significant. Significance of this trend has been obtained by applying a circular "bootstrap" technique that is shown in Turco and Llasat (2011). Considering the total annual number of floods for all the regions, a positive trend of 0.25 floods $\mathrm{yr}^{-1}$ was obtained, as for the extraordinary ones, which show a trend of 0.13 floods $\mathrm{yr}^{-1}$, with both trends significant at $95 \%$ (Fig. 7).

\section{Conclusions}

A common database that covers a period of $30 \mathrm{yr}$, 19812010, is being built within the framework of the HYMEX programme. The main objectives of this database are to obtain a complete list of floods and flash flood events that have affected the region of study in order to provide useful information for future studies; to evaluate the importance of minor but frequent events that usually are not considered; to

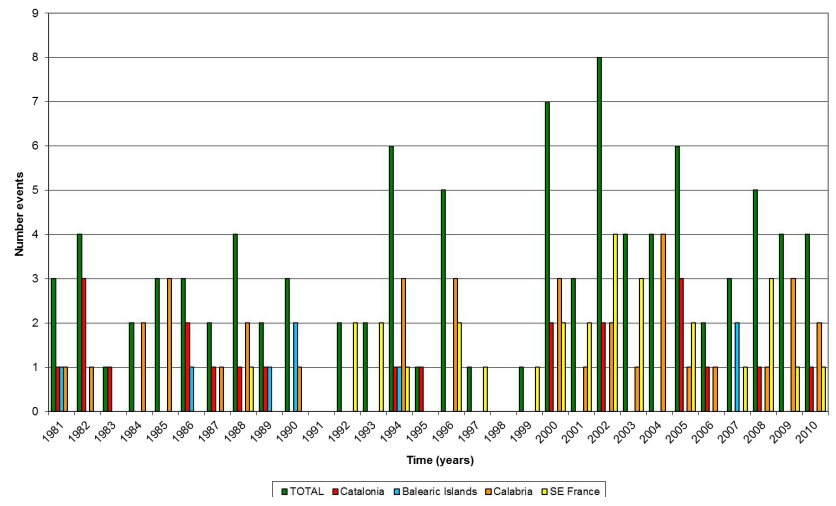

Fig. 6. Interannual evolution of catastrophic floods for the period 1981-2010.

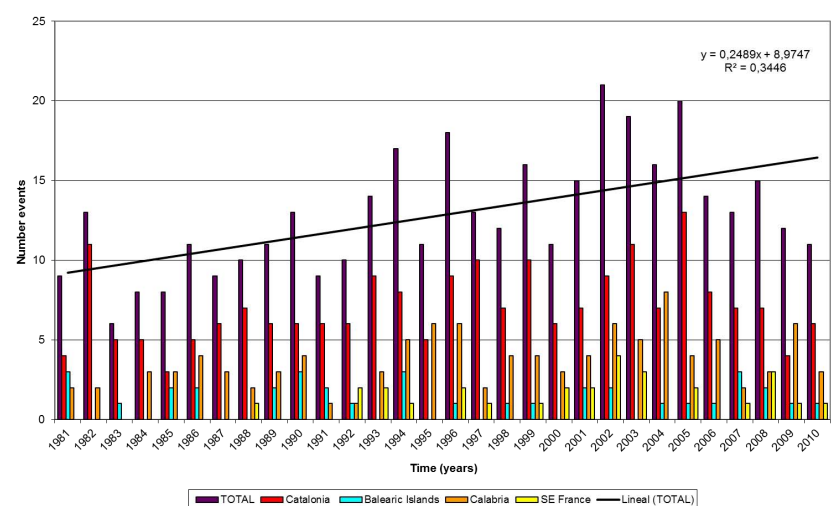

Fig. 7. Interannual flood evolution for all the analysed regions for the period 1981-2010.

identify those events that have affected large regions in order to conduct future studies; and to improve the knowledge of fatalities due to floods and the circumstances of the deaths, the economic impact and its evolution, and the societal perception and factors involved. They also have to answer the need for an accurate and standardised monitoring of damage (human and material) and the possibility of testing the connection between the hazard data (rainfall threshold, specific discharge) and the consequences of floods. Eventually, this database might prove to be a great help in assessing the efficiency of the mitigation measures and the possibility of improving them.

In this preliminary study, 385 flood events (including flash-flood events) that affected one or more of the selected regions (Catalonia and the Balearic Islands in Spain, Languedoc-Roussillon Midi-Pyrénées and Provence-Alpes Côte d'Azur in France, and Calabria in Italy) were identified. $55.3 \%$ of these events affected Catalonia, $27.7 \%$ Calabria, $9.3 \%$ Balearic Islands and $7.5 \%$, the south of France. Most of them produced extraordinary floods (47.2\%), while only $24.6 \%$ were catastrophic events. As a consequence of these 385 flood events, 333 people have died, mainly due to 
Table A1. Catastrophic floods recorded between 1981 and 2010 in the selected regions of the study (Keywords: FL: flood, FF: flash flood, HL: hail, LS: landslide, SN: snow, SW: strong wind, TO: tornado). Regions: CAL: Calabria (Italy), BAL: Balearic Islands (Spain), CAT: Catalonia (Spain), PACA: Provence-Alpes-Côte d'Azur (France), LR: Languedoc-Roussillon (France), MP: Midi-Pyrénées (France).

\begin{tabular}{|c|c|c|c|c|c|c|c|c|}
\hline Initial date & Final date & Country & Region & Kind of event & $\begin{array}{l}\text { Site-Total rain or } \\
\text { Site-daily rain } \\
{\left[R_{\mathrm{d}}\right] \text { or intensity }} \\
{\left[R_{\text {hours }}\right](\mathrm{mm})}\end{array}$ & Casualties & $\begin{array}{r}\text { Number } \\
\text { municipa- } \\
\text { lities } \\
\text { affected }\end{array}$ & $\begin{array}{l}\text { Estimated } \\
\text { economic } \\
\text { damages } \\
(\mathrm{M}=\text { Million })\end{array}$ \\
\hline 19810103 & 19810210 & Italy & CAL & LS, SW, FL, FF, HL, SN & Rende- $R_{\mathrm{d}}=119.2$ & 0 & 61 & 1730 billion $£$ \\
\hline 19810421 & 19810421 & Spain & BAL & FL & $S^{\prime}$ Hort Nou- $R_{24 \mathrm{~h}}=176$ & 1 & 5 & unknown \\
\hline 19810627 & 19810628 & Spain & CAT & FL, LS, HL, SN & Total: Borges del Camp-235 & 0 & 2 & $>1 \mathrm{M} \mathrm{Pts}$ \\
\hline 19820216 & 19820218 & Spain & CAT & FL, SN & Amer- $R_{24 \mathrm{~h}}=251.2$ & 1 & 33 & $360 \mathrm{MPts}$ \\
\hline 19820804 & 19820804 & Spain & CAT & $\mathrm{FF}$ & Calella $-R_{24 \mathrm{~h}}=87$ & 1 & 9 & $>200 \mathrm{MPts}$ \\
\hline 19821028 & 19821029 & Italy & CAL & FL, FF, LS & Serra S. Bruno- $R_{\mathrm{d}}=221$ & 1 & 9 & unknown \\
\hline 19821106 & 19821108 & Spain & CAT & FL, LS, SW & $\begin{array}{l}\text { Total: La Molina-556; } \\
\text { La Molina- } R_{24 \mathrm{~h}}=341.8\end{array}$ & 14 & 99 & $\begin{array}{l}45 \text { 000M Pts. EM- } \\
\text { DAT: } 300 \mathrm{M} \$ \text {. Mu- } \\
\text { nich Re: } 375 \mathrm{M} \$\end{array}$ \\
\hline 19831106 & 19831108 & Spain & CAT & FL & Rubi- $R_{24 \mathrm{~h}}=367$ & 3 & 14 & $10000 \mathrm{M}$ Pts \\
\hline 19840405 & 19840410 & Italy & CAL & FL, FF, LS, SW & Feroleto- $R_{\mathrm{d}}=108.1$ & 0 & 14 & $70 \mathrm{M} £$ \\
\hline 19841229 & 19850123 & Italy & CAL & FL, FF, LS, SN & Serra S.Bruno- $R_{3 \mathrm{~d}}=197.4$ & 0 & 76 & unknown \\
\hline 19850309 & 19850330 & Italy & CAL & FL,FF, LS, SW, SN & Rizziconi- $R_{\mathrm{d}}=153.1$ & 0 & 36 & $200 \mathrm{M} £$ \\
\hline 19850418 & 19850420 & Italy & CAL & FL, FF, LS, SW, SN & Rossano- $R_{\mathrm{d}}=165.1$ & 0 & 9 & unknown \\
\hline 19851030 & 19851031 & Italy & CAL & FL, FF, LS & Botricello- $R_{\mathrm{d}}=158$ & 0 & 26 & $580 \mathrm{M} £$ \\
\hline 19860906 & 19860906 & Spain & CAT & FF, HL & Segarra $-R_{45 \min }=200$ & 0 & 2 & $>30 \mathrm{M} \mathrm{Pts}$ \\
\hline 19861012 & 19861015 & Spain & CAT & FL & Cadaqués- $R_{24 \mathrm{~h}}=430$ & 0 & 11 & unknown \\
\hline 19861118 & 19861118 & Spain & BAL & FL, FF & Soller $-R_{24 \mathrm{~h}}=140$ & 0 & 1 & unknown \\
\hline 19870928 & 19871005 & Spain & CAT & FL & Portbou- $R_{24 \mathrm{~h}}=300$ & 10 & 78 & $8000 \mathrm{M}$ Pts \\
\hline 19871115 & 19871116 & Italy & CAL & LS, FL, FF & Borgia- $R_{\mathrm{d}}=330$ & 0 & 35 & $1.8 \mathrm{~B} £$ \\
\hline 19880302 & 19880315 & Italy & CAL & FL, FF, LS, SW, SN & Agnana- $R_{\mathrm{d}}=415$ & 0 & 72 & $1.4 \mathrm{~B} £$ \\
\hline 19881003 & 19881003 & France & LR & FF, LS & $\begin{array}{l}\text { Nîmes Mas de Ponge- } R_{24 \mathrm{~h}}= \\
420 ; R_{1 \mathrm{~h}}=50\end{array}$ & 10 & & $\begin{array}{l}610 \mathrm{M} € \\
(290 \mathrm{M} \text { insured) }\end{array}$ \\
\hline 19881108 & 19881113 & Spain & CAT & FL, LS & $\begin{array}{l}\text { Corbera de Llobregat }-R_{24 \mathrm{~h}}= \\
225\end{array}$ & 9 & 28 & $5681 \mathrm{M}$ Pts \\
\hline 19881114 & 19881116 & Italy & CAL & FL, FF, LS & Gambarie- $R_{\mathrm{d}}=170$ & 0 & 11 & unknown \\
\hline 19890906 & 19890906 & Spain & BAL & FL & Felanitx- $R_{24 \mathrm{~h}}=250$ & 3 & 10 & unknown \\
\hline 19891114 & 19891118 & Spain & CAT & FL, SW, LS, SN, HL & Portbou- $R_{24 \mathrm{~h}}=258$ & 0 & 18 & unknown \\
\hline 19901008 & 19901009 & Spain & BAL & FL & Escorca- $R_{24 \mathrm{~h}}=250$ & 0 & 10 & unknown \\
\hline 19901110 & 19901110 & Spain & BAL & FL & Son Servera- $R_{24 \mathrm{~h}}=141.7$ & 1 & 6 & unknown \\
\hline 19901224 & 19901228 & Italy & CAL & FL, FF, LS, SW & Cerenzia- $R_{\mathrm{d}}=181$ & 0 & 40 & $1.575 \mathrm{~B} £$ \\
\hline 19920922 & 19920922 & France & PACA & $\mathrm{FF}$ & $\begin{array}{l}\text { Total: Entrechaux }=300 ; \\
\text { Carpentras- } R_{1 \mathrm{~h}}=85.8\end{array}$ & 47 & & $\begin{array}{l}500 \mathrm{M} € \\
(244 \mathrm{M} \text { insured })\end{array}$ \\
\hline 19920926 & 19920927 & France & LR & FF, SW & $\begin{array}{l}\text { Total: Mont Hèlène-324; } \\
\text { Vernet-les-bains- } R_{1 \mathrm{~h}}=82\end{array}$ & 3 & & $50 \mathrm{M} €$ \\
\hline 19930901 & 19931101 & France & PACA & FL & Antraigues- $R_{\text {October }}=834$ & 10 & & $\begin{array}{l}594 \mathrm{M} € \\
(305 \mathrm{M} \text { insured) }\end{array}$ \\
\hline 19931201 & 19940101 & France & PACA & FL, SW & Plateau d'Albion- $R_{36 \mathrm{~h}}=300$ & 10 & & $\begin{array}{l}530 \mathrm{M} € \\
(260 \mathrm{M} € \text { €insured })\end{array}$ \\
\hline 19940110 & 19940127 & Italy & CAL & FL, LS & Siderno $R_{24 \mathrm{~h}}=42.2$ & 0 & & $4.5 \mathrm{~B} £$ \\
\hline
\end{tabular}


Table A1. Continued.

\begin{tabular}{|c|c|c|c|c|c|c|c|c|}
\hline & & & & & $\begin{array}{l}\text { Site-Total rain or } \\
\text { Site-daily rain } \\
{\left[R_{\mathrm{d}}\right] \text { or intensity }}\end{array}$ & & $\begin{array}{r}\text { Number } \\
\text { municipa- } \\
\text { lities }\end{array}$ & $\begin{array}{l}\text { Estimated } \\
\text { economic } \\
\text { damages }\end{array}$ \\
\hline 19940215 & 19940223 & Italy & CAL & F, LS, SW & Cirò Marina $R_{24 \mathrm{~h}}=56.3$ & 0 & & 2670B $£$ \\
\hline 19941009 & 19941011 & Spain & CAT & FL & $\begin{array}{l}\text { Cornudella de } \\
\text { Montsant }-R_{24 \mathrm{~h}}=397\end{array}$ & 10 & 63 & $>23$ 400M Pts \\
\hline 19941018 & 19941020 & Spain & BAL & FF, FL & $\begin{array}{l}\text { Total: Fornalutx }=327.7 \\
\text { Fornalutx- } R_{24 \mathrm{~h}}=194\end{array}$ & 0 & 3 & $3.62 \mathrm{M} €$ \\
\hline 19941104 & 19941106 & Italy & CAL & FL, LS & Staiti $R_{24 \mathrm{~h}}=231.2$ & 0 & & unknown \\
\hline 19941105 & 19941106 & France & PACA & $\mathrm{FF}$ & La Martre- $R_{\mathrm{d}}=150$ & 0 & & $120 \mathrm{M} €$ \\
\hline 19950921 & 19950921 & Spain & CAT & FF, SW, HL & Fabra- $R_{24 \mathrm{~h}}=253$ & 1 & 19 & $\begin{array}{l}\text { 4000M Pts } \\
\text { (insured) }\end{array}$ \\
\hline 19960101 & 19960208 & Italy & CAL & FL, FF, LS, SW & Petilia- $R_{\mathrm{d}}=183.2$ & 0 & 76 & unknown \\
\hline 19960128 & 19960130 & France & LR & FF & Brenas- $R_{\mathrm{d}}=206$ & 4 & & EM-DAT: 6 M US\$ \\
\hline 19961003 & 19961009 & Italy & CAL & FL, FF, LS, SW & S. Cristina- $R_{\mathrm{d}}=236.2$ & 6 & 189 & $60 \mathrm{~B} £$ \\
\hline 19961014 & 19961014 & Italy & CAL & FL, LS, HP, SS & Crotone- $R_{24 \mathrm{~h}}=115.2$ & 6 & & $25 \mathrm{~B} £$ \\
\hline 19961206 & 19961212 & France & LR & $\mathrm{FF}$ & Palairac- $R_{\mathrm{d}}=212.2$ & 4 & & $\begin{array}{l}80 \mathrm{M} € \text { (nearly } \\
80 \mathrm{M} \text { insured) }\end{array}$ \\
\hline 19971216 & 19971219 & France & LR & $\mathrm{FF}$ & Villefort- $R_{\mathrm{d}}=256.6$ & 0 & & unknown \\
\hline 19991112 & 19991114 & France & LR, MP & FL, FF, SW, LS & $\begin{array}{l}\text { Total: Lézignan- } R_{\mathrm{t}}=622.4 \\
\text { Lézignan- } R_{\mathrm{d}}=551.2\end{array}$ & 36 & 438 & $\begin{array}{l}533 \mathrm{M} € \\
(260 \mathrm{M} \text { insured })\end{array}$ \\
\hline 20000113 & 20000120 & Italy & CAL & FL, FF, LS, SW & Cittanova- $R_{\mathrm{d}}=132.4$ & 0 & 26 & unknown \\
\hline 20000417 & 20000420 & Italy & CAL & FL, FF, LS, SW & Castellace- $R_{\mathrm{d}}=110$ & 0 & 6 & unknown \\
\hline 20000610 & 20000614 & Spain & CAT & FL, LS, SW & Rajadell- $R_{24 \mathrm{~h}}=224$ & 5 & 27 & $65 \mathrm{M} €$ \\
\hline 20000907 & 20001012 & Italy & CAL & FF, LS, SW & Ardore S.- $R_{\mathrm{d}}=425$ & 13 & 98 & $20 \mathrm{~B} £$ \\
\hline 20000919 & 20000920 & France & PACA & FF, SW & $\begin{array}{l}\text { Marseille- } R_{\mathrm{d}}=200 \\
R_{3 \mathrm{~h}}=158\end{array}$ & 0 & 14 & $50 \mathrm{M} €$ \\
\hline 20001019 & 20001026 & Spain & CAT & FL, LS & Arnés- $R_{24 \mathrm{~h}}=319$ & 5 & 21 & $\begin{array}{l}90 \mathrm{M} € \text { (insured). } \\
\text { EM-DAT: } 75 \mathrm{M} \$\end{array}$ \\
\hline 20001105 & 20001107 & France & PACA & FF, LS & Luceram- $R_{\mathrm{d}}=114.6$ & 0 & 80 & $\begin{array}{l}50 \mathrm{M} € \\
(47 \mathrm{M} \text { insured) }\end{array}$ \\
\hline 20010113 & 20010120 & Italy & $\mathrm{CAL}$ & LS, FL, FF, SW & Trebisacce- $R_{\mathrm{d}}=108$ & 0 & 15 & $6.5 \mathrm{~B} £$ \\
\hline 20011006 & 20011007 & France & LR & $\mathrm{FF}$ & Cardet $-R_{\mathrm{d}}=355$ & 2 & & unknown \\
\hline 20011009 & 20011009 & France & LR & FF & Prades le Lez- $R_{\mathrm{d}}=115.6$ & 0 & & unknown \\
\hline 20020524 & 20020524 & Italy & CAL & LS, FL & Arena- $R_{24 \mathrm{~h}}=133.2$ & 0 & 15 & unknown \\
\hline 20020731 & 20020801 & Spain & CAT & FL, LS & Total: Montgat-248 & 0 & 13 & $7.5 \mathrm{M} €$ \\
\hline 20020908 & 20020912 & France & PACA, LR & FL, FF & $\begin{array}{l}\text { Total: Anduze- } R_{\mathrm{t}}=687 ; \\
\text { Cardet }-R_{24 \mathrm{~h}}=682.6 ; \\
\text { Générargues- } R_{1 \mathrm{~h}}=123.7\end{array}$ & 25 & 419 & $\begin{array}{l}1200 \mathrm{M} € \\
\text { (670 M insured) }\end{array}$ \\
\hline 20021008 & 20021010 & Spain & CAT & FL & S.Joan Despí- $R_{24 \mathrm{~h}}=174.1$ & 0 & 14 & 12.4 $\mathrm{M} €$ (insured) \\
\hline 20021114 & 20021119 & France & PACA & $\mathrm{FF}$ & S. Martin Vésubie- $R_{\mathrm{d}}=247.4$ & 1 & 100 & unknown \\
\hline 20021122 & 20030211 & Italy & CAL & FL, FF, LS, SW, HL, SN & Serra S.Bruno- $R_{24 \mathrm{~h}}=108$ & 0 & 135 & $\begin{array}{l}2 \mathrm{M} € . \text { EM-DAT: } \\
350 \mathrm{M} \$\end{array}$ \\
\hline 20021123 & 20021129 & France & PACA, LR & FF & $\begin{array}{l}\text { Saint Cezaire sur Siagne- } R_{\mathrm{d}}= \\
132.4\end{array}$ & 1 & 100 & unknown \\
\hline 20021210 & 20021212 & France & LR & FL, FF, SW & $\begin{array}{l}\text { Total: S. Martin de Londres- } \\
R_{\mathrm{t}}=302 ; \quad \mathrm{S} \text {. Martin de } \\
\text { Londres- } R_{\mathrm{d}}=158.2\end{array}$ & 2 & 65 & 700000 \\
\hline
\end{tabular}


Table A1. Continued.

\begin{tabular}{|c|c|c|c|c|c|c|c|c|}
\hline & & & & & $\begin{array}{l}\text { Site-Total rain or } \\
\text { Site-daily rain } \\
{\left[R_{\mathrm{d}}\right] \text { or intensity }}\end{array}$ & & $\begin{array}{r}\text { Number } \\
\text { municipa- } \\
\text { lities }\end{array}$ & $\begin{array}{l}\text { Estimated } \\
\text { economic } \\
\text { damages }\end{array}$ \\
\hline 20030203 & 20030204 & France & MP & FL, FF & Angles- $R_{\mathrm{d}}=100$ & 1 & 67 & unknown \\
\hline 20030922 & 20030922 & France & LR, PACA & FL, FF, LS, TO & Générac- $R_{\mathrm{d}}=280$ & 0 & 71 & unknown \\
\hline 20031201 & 20031210 & France & PACA, LR, MP & FL, FF, SW, LS & $\begin{array}{l}\text { Total : La Souche- } R_{\mathrm{t}}=442 ; \\
\text { Antraigues sur Volane- } R_{\mathrm{d}}= \\
251.2\end{array}$ & 7 & 1533 & $\begin{array}{l}1500 \mathrm{M} € \\
\text { (768 } \mathrm{M} \text { insured). }\end{array}$ \\
\hline 20031208 & 20031223 & Italy & $\mathrm{CAL}$ & FL, FF, SW, LS, SN & Pizzoni- $R_{\mathrm{d}}=161.4$ & 1 & 40 & unknown \\
\hline 20040124 & 20040209 & Italy & CAL & FL, FF, LS, SW & S.Sosti- $R_{\mathrm{d}}=165.8$ & 0 & 10 & unknown \\
\hline 20040304 & 20040311 & Italy & CAL & FL, LS, SN & Cropani $R_{24 \mathrm{~h}}=80.2$ & 0 & & unknown \\
\hline 20041103 & 20041118 & Italy & $\mathrm{CAL}$ & FL, FF, LS, SW, HL & Parenti- $R_{\mathrm{d}}=221.8$ & 1 & 69 & $10 \mathrm{M} €$ \\
\hline 20041209 & 20041220 & Italy & CAL & FF, FL, LS, SW & Chiaravalle- $R_{\mathrm{d}}=186$ & 0 & 33 & unknown \\
\hline 20050119 & 20050209 & Italy & $\mathrm{CAL}$ & FL, LS, SW, SN, HL & Acri $R_{24 \mathrm{~h}}=45.8$ & 0 & & unknown \\
\hline 20050905 & 20050908 & Spain & CAT & FL, LS, TO, SW & La Jonquera- $R_{24 \mathrm{~h}}=54$ & 2 & 26 & $>11 \mathrm{M} €$ \\
\hline 20050905 & 20050909 & France & PACA & $\mathrm{FF}$ & $\begin{array}{l}\text { Générac- } R_{\mathrm{d}}=298 ; \\
\text { Conqueyrac- } R_{1 \mathrm{~h}}=64.2\end{array}$ & 2 & 241 & $100 \mathrm{M} €$ insured \\
\hline 20051011 & 20051015 & Spain & CAT & FL, LS & $\begin{array}{l}\text { Total: Castell d'Aro-350; } \\
\text { Serra d'Aro- } R_{24 \mathrm{~h}}=132.4\end{array}$ & 4 & 33 & $>12.5 \mathrm{M} €$ \\
\hline 20051113 & 20051115 & France & LR & FL, FF & Palairac- $R_{\mathrm{d}}=250$ & 0 & 79 & $\begin{array}{l}20 \mathrm{M} € \\
(17 \mathrm{M} \text { insured })\end{array}$ \\
\hline 20051113 & 20051115 & Spain & CAT & FL, HL, LS, SN, SW & $\begin{array}{l}\text { Total: S. Pere de Ribes- } 212.4 \\
\text { Montral- } R_{24 \mathrm{~h}}=121.5\end{array}$ & 1 & 8 & $1.5 \mathrm{M} €$ \\
\hline 20060703 & 20060704 & Italy & CAL & FL, LS, SW, FF & Vibo V.- $R_{\mathrm{d}}=202 ; R_{2 \mathrm{~h}}=190$ & 3 & 18 & $1 \mathrm{M} €$ \\
\hline 20060912 & 20060914 & Spain & CAT & FL, TO, LS & $\begin{array}{l}\text { Total: Constantí-267.3; } \\
\text { Vandellós- } R_{24 \mathrm{~h}}=84.6\end{array}$ & 1 & 37 & $76.5 \mathrm{M} €$ \\
\hline 20070525 & 20070526 & France & MP & FL, FF, LS & $\begin{array}{l}\text { Total: } \text { Bourg- } R_{\mathrm{t}}=166 ; \\
\text { Carla-Bayle- } R_{\mathrm{d}}=105.3\end{array}$ & 0 & 72 & $17 \mathrm{M} €$ insured \\
\hline 20071004 & 20071004 & Spain & BAL & FL & Palma- $R_{24 \mathrm{~h}}=23.8$ & 1 & 3 & unknown \\
\hline 20071017 & 20071017 & Spain & BAL & FL & $\begin{array}{l}\text { Total: Esporles-113; } \\
\text { Esporles- } R_{1 \mathrm{~h}}=80\end{array}$ & 1 & 5 & unknown \\
\hline 20080526 & 20080530 & France & PACA & FF, SN & Ristolas- $R_{\mathrm{d}}=185.9$ & 0 & 41 & unknown \\
\hline 20081101 & 20081105 & France & LR & $\mathrm{FF}$ & Villefort- $R_{\mathrm{d}}=427.8$ & 0 & 590 & $160 \mathrm{M} €$ insured \\
\hline 20081102 & 20081102 & Spain & CAT & FF, SW, LS, SN & Non data & 0 & 4 & unknown \\
\hline 20081210 & 20081218 & Italy & CAL & FL, FF, LS, SW & Molochio- $R_{\mathrm{d}}=277$ & 1 & 110 & EM-DAT: $278 \mathrm{M} \$$ \\
\hline 20081214 & 20081217 & France & PACA & FF, SW, LS & $\begin{array}{l}\text { Total. Bormes- } R_{\mathrm{t}}=201 \\
\text { Methamis- } R_{\mathrm{d}}=139\end{array}$ & 1 & 125 & $49 \mathrm{M} €$ insured \\
\hline 20090109 & 20090225 & Italy & CAL & FL, FF, LS, SW, HL & S. Cristina- $R_{\mathrm{d}}=310.2$ & 0 & 236 & unknown \\
\hline 20090918 & 20090919 & France & PACA & $\mathrm{FF}$ & $\begin{array}{l}\text { Total: Cogolin- } R_{\mathrm{t}}=182 \\
\text { Cogolin- } R_{\mathrm{d}}=174\end{array}$ & 0 & 41 & $65 \mathrm{M} €$ insured \\
\hline 20090921 & 20091003 & Italy & CAL & FL, FF, LS, SW, HL & Chiaravalle- $R_{\mathrm{d}}=336$ & 0 & 90 & unknown \\
\hline 20091217 & 20091219 & Italy & CAL & FL, LS & Nicastro Bella $R_{24 \mathrm{~h}}=106$ & 0 & & unknown \\
\hline 20100115 & 20100301 & Italy & CAL & FL, FF, LS, SW & Petronà- $R_{\mathrm{d}}=234$ & 0 & 67 & unknown \\
\hline 20100614 & 20100616 & France & PACA & $\mathrm{FF}$ & $\begin{array}{l}\text { Les Arcs- } R_{\mathrm{d}}=397 \\
\text { Lorgues- } R_{1 \mathrm{~h}}=83.5\end{array}$ & 25 & 59 & $\begin{array}{l}1000 \mathrm{M} € \\
(615 \mathrm{M} \text { insured) }\end{array}$ \\
\hline 20101010 & 20101013 & Spain & CAT & FL, LS, SW & Total: La Jonquera-> 300 & 1 & 8 & unknown \\
\hline 20101012 & 20101130 & Italy & CAL & FL, LS & Rizziconi- $R_{\mathrm{d}}=199$ & 0 & 75 & unknown \\
\hline
\end{tabular}


catastrophic events $(46.3 \%$ of catastrophic events produced casualties), but also due to extraordinary floods (10.4\% of these flood events produced casualties). Considering the total number of casualties, $5 \%$ of them have been as a consequence of extraordinary floods associated with minor damage. $55 \%$ of the victims were swept away by the water when crossing torrential streams, which points to the possibility of reducing the number of casualties through better risk awareness.

Comparison with the EM-DAT and NATHAN databases has shown that these global databases do not include all the catastrophic events that occurred in the regions of study for the period analysed, nor all the casualties or the extraordinary floods. Indeed, only $5.9 \%$ of the identified events in the FLOODHYMEX database are included in the EM-DAT databases, and this percentage decreases to $2 \%$ when we refer to the NATHAN database.

Catastrophic floods usually produce traffic disruption and, in some occasions partial destruction of the roads and railway network and bridges. The services sector is also usually affected, and more than $80 \%$ of the events caused major damage to buildings or monuments and to historical sites. The worst affected (by direct damage) productive sector is agriculture (62\% of the cases), followed by commerce and handicrafts $(54 \%)$, tourism $(45 \%)$ and industry $(29 \%)$. However, it is difficult to obtain detailed information from each event about damage or specifying the number of roads, buildings, and so on, affected, and consequently they can be considered only as qualitative indicators. Unfortunately, detailed information from insurances companies is not available either.

Although autumn is the most flood-prone season (with the exception of Calabria, in which it is winter), floods may be also recorded in summer, connected with short convective processes that affect torrential rivers, usually located at the coast in very densely populated areas with substantial tourist activity. In spite of catastrophic floods not showing a significant positive trend, the total number of floods does show an increase of 0.25 floods $\mathrm{yr}^{-1}$, which is probably related with a change in the uses of soil, but also with an increasing vulnerability.

Acknowledgements. This paper has been undertaken within the framework of the HYMEX project and DRHIM Project (G.A. no. 283568 EC 7th Framework Programme). Our acknowledgement to Raül Marcos for his collaboration in the trend analysis, and to Joan Gilabert for his collaboration in database construction.

Edited by: G. Boni

Reviewed by: D. Miozzo and one anonymous referee

\section{References}

Altava-Ortiz, V., Llasat, M. C., Ferrari, E., Atencia, A., and Sirangelo, B.: Monthly rainfall changes in central and Western Mediterranean basins, at the end of the 20th and beginning of the 21st centuries, Int. J. Climatol., 31, 1943-1958, 2010.

Amaro, J., Gayà, M., Aran, M., and Llasat, M. C.: First results of the Social Impact Research Group in Catalonia and the Balearic Islands, 5th HyMeX Workshop, 17-19 May 2011, Menorca, Spain, 2011.

Barriendos, M., Coeur, D., Lang, M., Llasat, M. C., Naulet, R., Lemaitre, F., and Barrera, A.: Stationarity analysis of historical flood series in France and Spain (14th-20th centuries), Nat. Hazards Earth Syst. Sci., 3, 583-592, doi:10.5194/nhess-3-5832003, 2003.

Barrera, A., Llasat, M. C., and Barriendos, M.: Estimation of extreme flash flood evolution in Barcelona County from 1351 to 2005, Nat. Hazards Earth Syst. Sci., 6, 505-518, doi:10.5194/nhess-6-505-2006, 2006.

Barberia, L., Amaro, J., Aran, M., and Llasat, M. C.: Social impact analysis of two heavy rain events in Catalonia: 14 and 15 July 2001 and 3 April 2002, Plinius Conference on Mediterranean Storms. Disasters and Climate Change: knowing how to adapt, Savona, Italy, 7-9 September 2011, Programme Book, contribution 13-57, 2011.

Barnolas, M. and Llasat, M. C.: A flood geodatabase and its climatological applications: the case of Catalonia for the last century, Nat. Hazards Earth Syst. Sci., 7, 271-281, doi:10.5194/nhess-7271-2007, 2007a.

Barnolas, M. and Llasat, M. C.: Estudio de las inundaciones históricas en cuencas españolas. Metodología y desarrollo de un sistema de información geográfico. Aplicación a las cuencas del Ter, Segre y Llobregat. Monografía CEDEX, 264 pp., Ministerio de Fomento, ISBN:978-84-7790-449-6, Madrid, 2007b.

Barredo, J. I.: Normalised flood losses in Europe: 1970-2006, Nat. Hazards Earth Syst. Sci., 9, 97-104, doi:10.5194/nhess-9-972009, 2009.

Barredo, J. I., Saurí, D., and Llasat, M. C.: Assessing trends in insured losses from floods in Spain 1971-2008, Nat. Hazards Earth Syst. Sci., 12, 1723-1729, doi:10.5194/nhess-12-17232012, 2012.

Camuffo, D. and Enzi, S.: The analysis of two bi-millennial series: Tiber and Po river floods, in: Climatic Variations and Forcing Mechanisms of the Last 2000 Years, edited by: Jones, P. D., Bradley, R. S., and Jouzel, J., Springer, Berlin, 433-450, 1996.

Di Mauro, M., De Bruijn, K. M., and Meloni, M.: Quantitative methods for estimating flood fatalities: towards the introduction of loss-of-life estimation in the assessment of flood risk, Nat. Hazards, 63, 1083-1113, doi:10.1007/s11069-012-0207-4, 2012.

Gaume, E., Bain, V., Bernardaza, P., Newinger, O., Barbuc, M., Bateman, A., Blaskovicová, L., Blöschl, G., Borga, M., Dumitrescu, A., Daliakopoulos, I., Garcia, J., Irimescu, A., Kohnova, S., Koutroulis, A., Marchi, L., Matreata, S., Medina, V., Preciso, E., Sempere-Torres, D., Stancalie, G., Szolgay, J., Tsanis, J., Velasco, D., and Viglione, A.: A compilation of data on European flash floods, J. Hydrol., 367, 70-78, 2009.

Grimalt, M.: La geografia del risc a Mallorca. Les inundacions, Institut d'Estudis Balearics, Palma de Mallorca, 1992.

Grimalt, M. and Rosselló, J.: Historical flash flood impact in Mallorca and its future evolution, 4th HYMEX Workshop, June 
2010, Bologna, Italy, 2010.

Grimalt, M. and Rosselló, J.: Reconstruction of the 1403 flood of Palma (Mallorca) from historical sources, 5th HyMeX Workshop, 17-19 May 2011. Menorca, Spain, 2011.

Guzzetti, F., Cardinali, M., and Reichenbach, P.: The AVI Project: A bibliographical and archive inventory of landslides and floods in Italy, Environ. Manage., 18, 623-633, 1994.

Jonkman, S. N. and Vrijling, J. K.: Loss of life due to floods, J. Flood Risk Manage., 1, 43-56, 2008.

Llasat, M. C., Versace, P., and Ferrari, E.: Heavy rains and flash floods, Proceedings of the Joint Session of Topic IV (Rare Floods) and Topic VI (Heavy rains). FRIEND, UNESCO IHPV 1.1 Project AMHY Group. National Research Council, Group for Prevention of Hydrogeological Disasters, Public. No. 2049, 139 pp., Cosenza, Italia, 1999.

Llasat, M. C., Barriendos, M., Barrera, A., and Rigo, T.: Floods in Catalonia (NE Spain) since the 14th century. Climatological and meteorological aspects from historical documentary sources and old instrumental records, Applications of palaeoflood hydrology and historical data in flood risk analysis, J. Hydrol., 313, 32-47, 2005.

Llasat, M. C., Llasat-Botija, M., and López, L.: A press database on natural risks and its application in the study of floods in Northeastern Spain, Nat. Hazards Earth Syst. Sci., 9, 2049-2061, doi:10.5194/nhess-9-2049-2009, 2009.

Llasat, M. C., Llasat-Botija, M., Rodríguez, A., and Lindbergh, S.: Flash floods in Catalonia: a recurrent situation, Adv. Geosci., 26, 105-111, 2010a, http://www.adv-geosci.net/26/105/2010/.

Llasat, M. C., Llasat-Botija, M., Prat, M. A., Porcú, F., Price, C., Mugnai, A., Lagouvardos, K., Kotroni, V., Katsanos, D., Michaelides, S., Yair, S., Savvidou, K., and Nicolaides, K.: Highimpact floods and flash floods in Mediterranean countries: the flash preliminary database, Adv. Geosci., 23, 1-9, 2010b, http://www.adv-geosci.net/23/1/2010/.

Llasat, M. C., Amaro, J., Aran, M., Boissier, L., Boudevillain, B., Creutin, J. D., Lutoff, C., Llasat-Botija, M., Petrucci, O., Rosselló, J., Ruin, I., Saurí, D., Vinet, F., and Drobinski, P.: HyMeX - Contribution on Social Impact. HyMeX cluster of posters at the WCRP, OSC WCRP Conference, Denver, USA, 24-28 October 2011, Climate Research in Service to Society, $2011 \mathrm{a}$.

Llasat, M. C., Llasat-Botija, M., and Guamis, J.: Communication and perception of hydrometeorological risks in Catalonia, Plinius Conference on Mediterranean Storms, Disasters and Climate Change: knowing how to adapt, Savona, Italy, 7-9 September 2011, Programme Book, contribution 13-56, 2011 b.

Llasat, M. C., Llasat-Botija, M., Petrucci, O., Pasqua, A. A., Rosselló, J., Vinet, F., and Gajic-Capka, M.: Towards a database on societal impact of Mediterranean floods within the framework of the HYMEX project. 13th Plinius Conference on Mediterranean Storms. Disasters and Climate Change: knowing how to adapt, Savona, Italy, 7-9 September 2011, Programme Book, contribution 13-64, 2011c.
Lumbroso, D. M. and Vinet, F.: A comparison of the causes, effects and aftermaths of the coastal flooding of England in 1953 and France in 2010, Nat. Hazards Earth Syst. Sci., 11, 2321-2333, doi:10.5194/nhess-11-2321-2011, 2011.

MEDDTL (French Ministry of Environment): Tableau des événements naturels dommageables survenus en France de 1900 à 2010, available at: http://catalogue.prim.net/94), 2011.

Petrucci, O.: Assessment of the impact caused by natural disasters: simplified procedures and open problems, in: Managing Disasters - assessing hazards, emergencies and disaster impacts, edited by: Tiefenbacher, J. P., INTECH, Open Access Publisher, ISBN 979-953-307-006-2, 109-132, 2012.

Petrucci, O. and Pasqua, A. A.: The study of past damaging hydrogeological events for damage susceptibility zonation, Nat. Hazards Earth Syst. Sci., 8, 881-892, doi:10.5194/nhess-8-8812008, 2008.

Petrucci, O. and Pasqua, A. A.: A methodological approach to characterise Landslide Periods based on historical series of rainfall and landslide damage, Nat. Hazards Earth Syst. Sci., 9, 16551670, doi:10.5194/nhess-9-1655-2009, 2009.

Petrucci, O., Pasqua, A. A., and Polemio, M.: Flash flood occurrences since 17 th century in steep drainage basins in southern Italy, Environ. Manage., 50, 807-818, doi:10.1007/s00267-0129935-1, 2012.

Polemio, M. and Petrucci, O.: The occurrence of floods and the role of climate variations from 1880 in Calabria (Southern Italy), Nat. Hazards Earth Syst. Sci., 12, 129-142, doi:10.5194/nhess12-129-2012, 2012.

Price, C., Yair, Y., Mugnai, A., Lagouvardos, K., Llasat, M. C., Michaelides, S., Dayan, U., Dietrich, S., Di Paola, F., Galanti, F., Garrote, L., Harats, N., Katsanos, D., Kohn, M., Kotroni, V., Llasat-Botija, M., Lynn, B., Mediero, L., Morin, E., Nicolaides, K., Rozalis, S., Savvidou, K., and Ziv, B.: Using Lightning Data to Better Understand and Predict Flash Floods in the Mediterranean, Surv. Geophys., 32, 733-751, 2011.

Ruin, I., Creutin, J.-D., Anquetin, S., and Lutoff, C.: Human exposure to flash-floods - relation between flood parameters and human vulnerability during a storm of September 2002 in Southern France, J. Hydrol., 361, 199-213, 2008.

Servat, E., Boyer, J. F., Stanescu, V., Versace, P., Llasat, M. C., and Touaïbia, B.: Alpine and Mediterranean Friend (AMHY), FRIEND - a global perspective 1998-2002, edited by: Gustard, A. and Cole, G. A., CEH Wallingford UK, 29-39 pp., 2002.

Turco, M. and Llasat, M. C.: Trends in indices of daily precipitation extremes in Catalonia (NE Spain), 1951-2003, Nat. Hazards Earth Syst. Sci., 11, 3213-3226, doi:10.5194/nhess-11-32132011, 2011. 